\title{
Supporting Information: Radiosensitization by a Modified Nucleotide that Produces DNA Interstrand Cross-links Under Hypoxic Conditions.
}

In Seok Hong, Hui Ding, and Marc M. Greenberg*

Department of Chemistry, Johns Hopkins University

3400 N. Charles St.

Baltimore MD 21218

\section{Contents:}

1. General Methods. (S1-S5)

2. Supporting Information Figure 1. Incorporation velocity versus [dNTP] by Klenow exo(A) 8 (B) dTTP. (S6)

3. Supporting Information Figure 2. Primer extension by Klenow exo- in the presence of dATP, dCTP, and dGTP (1.0 mM) and (A) dTTP. (S7)

4. Supporting Information Figure 3. Formation of linearized duplex via Sequenase extension of primer hybridized to linearized M13mp7. (S8)

4. Supporting Information Figure 4. ${ }^{1} \mathrm{H}$ NMR of PhSedTTP (8). (S9)

5. Supporting Information Figure 5. ${ }^{31} \mathrm{P}$ NMR of PhSedTTP (8). (S9)

General Methods. Oligonucleotides were synthesized and characterized as previously described. $^{1,2}$ Radiolabeling was carried out using the standard protocols. ${ }^{3}$ Radio-labeled oligomers were hybridized with 1.5 eq. complementary oligomers in $10 \mathrm{mM}$ potassium phosphate $\left(\mathrm{pH}\right.$ 7.2) and $100 \mathrm{mM} \mathrm{NaCl}$ at $75{ }^{\circ} \mathrm{C}$ for $5 \mathrm{~min}$ and cooled to room temperature slowly.

Radiolysis of Duplex DNA. Radiolysis of oligonucleotides and plasmid DNA were carried out in Pyrex tubes using a ${ }^{137} \mathrm{Cs}$ irradiator (Gammacell 1000, dose rate $=8.2 \mathrm{~Gy} / \mathrm{min}$ ). DNA samples $(10-20 \mathrm{nM})$ were prepared in $10 \mathrm{mM}$ potassium phosphate $(\mathrm{pH} 7.2)$ and $100 \mathrm{mM} \mathrm{NaCl}$. After $\gamma$ radiation, samples were stored at room temperature in the dark for $2.5 \mathrm{~h}$. Oligonucleotide samples were mixed with $95 \%$ formamide loading buffer (samples: loading buffer $=1: 1 \mathrm{v} / \mathrm{v}$ ) and subjected to $20 \%$ denaturing PAGE analysis. For plasmid DNA after radiolysis, analyses were carried out using $1 \%$ alkaline agarose gel electrophoresis. ${ }^{3}$

Sample Preparation Under Hypoxic Conditions. For preparing samples under reduced $\mathrm{O}_{2}$ tension conditions, samples were initially degassed to remove the dissolved $\mathrm{O}_{2}$ using standard freeze-pump-thaw (three cycles, 3 min each) degassing techniques. $\mathrm{O}_{2}$ tension was adjusted by adding the gas mixtures of $\mathrm{O}_{2}(1 \%$ oxygen in argon or $21 \%$ oxygen (air)) and Ar, which were controlled using a mass flow controller (MKS instruments, 1179A types and 647C: 200, 500 sccm). For example, for the $0.17 \%$ oxygen tension, a flow rate of the $1 \%$ oxygen in $\operatorname{Ar}$ is 100 
$\mathrm{sccm}$, and flow rate of the $\mathrm{Ar}$ is $500 \mathrm{sccm}$. Each gas was mixed and carefully added to the already evacuated samples. The final pressure was fixed to the $360 \mathrm{mmHg}$ and the tubes were sealed using a torch.

ISC Growth Kinetics. $\gamma$-Radiolysis of 7 was carried out in Pyrex tubes using a ${ }^{137} \mathrm{Cs}$ irradiator (Shepherd Irradiator, dose rate $=23.5 \mathrm{~Gy} / \mathrm{min})$. DNA samples $(20 \mathrm{nM})$ were prepared in $10 \mathrm{mM}$ potassium phosphate (pH 7.2) and $100 \mathrm{mM} \mathrm{NaCl}$. After $\gamma$-radiolysis (10 min exposure, total 235 Gy), samples were stored at room temperature in the dark. $\mathrm{NaIO}_{4}(5 \mathrm{mM})$ reactions of $7(20 \mathrm{nM})$ were also carried out in $10 \mathrm{mM}$ potassium phosphate $(\mathrm{pH} \mathrm{7.2)}$ and $100 \mathrm{mM} \mathrm{NaCl}$ at room temperature. In both cases, aliquots were taken at the prescribed times and immediately quenched with an equal volume of $95 \%$ formamide loading buffer and stored at $-80{ }^{\circ} \mathrm{C}$ until subjecting to $20 \%$ denaturing PAGE analysis.

Preparation of the Plasmid DNA Containing Randomly Incorporated 1. M13mp7 (7,240 base pairs, circular ss plasmid) was digested with $E c o R$ I to produce a linearized ss plasmid $(7,200 \mathrm{nt})$. Restriction enzyme digestion of M13mp7 (50 pmol, $114 \mu \mathrm{g})$ with EcoR I (100 units) was carried out in $10 \mathrm{mM}$ Tris- $\mathrm{HCl}(\mathrm{pH} 7.9), 10 \mathrm{mM} \mathrm{MgCl}_{2}, 50 \mathrm{mM} \mathrm{NaCl}$, and $1 \mathrm{mM}$ dithiothreitol at $37{ }^{\circ} \mathrm{C}$ for $8 \mathrm{~h}$. After reaction, the solution was heated to $90{ }^{\circ} \mathrm{C}$ for $5 \mathrm{~min}$ and immediately cooled in ice water to inactivate the enzyme. Complete digestion of M13mp7 was confirmed by comparison of the mobility in $1 \%$ agarose gel electrophoresis between native plasmid and digested linear plasmid. Linearized plasmid (30 pmol) was hybridized with $5^{\prime}-{ }^{32} \mathrm{P}$ labeled primer (30 pmol, 5'-d(CAC TGA ATC ATG GTC ATA GCT GTT)) in $40 \mathrm{mM}$ Tris$\mathrm{HCl}$ (pH 7.5), $20 \mathrm{mM} \mathrm{MgCl}_{2}$, and $50 \mathrm{mM} \mathrm{NaCl}$ at $90{ }^{\circ} \mathrm{C}$ for $5 \mathrm{~min}$, followed by slow cooling to room temperature. Transformation of the linearized plasmid $(10 \mathrm{pmol})$ to duplex form was carried out following hybridization with $5{ }^{\prime}{ }^{32} \mathrm{P}$-primer in $40 \mathrm{mM}$ Tris- $\mathrm{HCl}(\mathrm{pH} 7.5), 20 \mathrm{mM}$

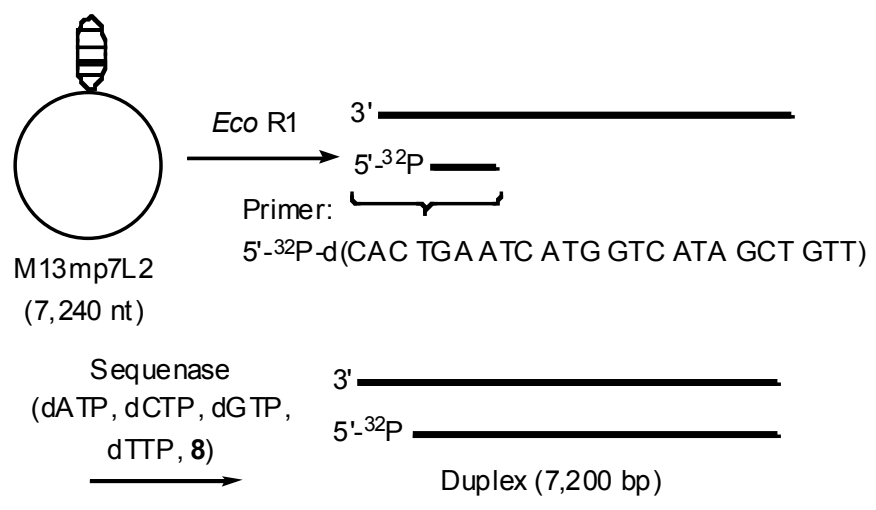


$\mathrm{MgCl}_{2}$, and $50 \mathrm{mM} \mathrm{NaCl}$. Extension was carried out using Sequenase (26 units, Version 2.0 DNA polymerase, US Biological) in the presence of equal concentrations of 8 and dTTP $(0.5$ $\mathrm{mM})$, along with the three other native dNTPs $(1.0 \mathrm{mM})$ at $37{ }^{\circ} \mathrm{C}$ for $30 \mathrm{~min}$. After reaction, plasmid duplex was purified by Microcon filter (molecular weight cut off, 30,000) to remove excess reagents. Complete polymerization of linearized M13mp7 was confirmed by $1 \%$ agarose gel electrophoresis using a molecular marker ( $1 \mathrm{kB}$ base ladder).

Synthesis of 5-Phenylselenylmethyl-2'-Deoxyuridine 5'-Triphosphate (8). To a solution of 5-Phenylselenylmethyl-2'-deoxyuridine $\quad(52 \mathrm{mg}, 0.13 \mathrm{mmol})$ and 1,8-bis(dimethylamino)naphthalene (Proton Sponge $\left.{ }^{\circledR}, 42 \mathrm{mg}, 0.19 \mathrm{mmol}\right)$ in trimethyl phosphate $(0.6$ $\mathrm{mL}$ ) cooled at $0{ }^{\circ} \mathrm{C}$, was added phosphorous oxytrichloride $(27 \mu \mathrm{L}, 0.29 \mathrm{mmol})$. After the mixture was stirred at $4{ }^{\circ} \mathrm{C}$ for $3 \mathrm{~h}$, a solution of tributylammonium pyrophosphate $(308 \mathrm{mg}, 0.65$ $\mathrm{mmol})$ in anhydrous DMF $(1.3 \mathrm{~mL})$ and tributylamine $(130 \mu \mathrm{L}, 0.55 \mathrm{mmol})$ was added dropwise via syringe over $5 \mathrm{~min}$. The reaction was stirred at room temperature for $2 \mathrm{~h}$, followed by quenching with $1 \mathrm{M}$ triethylammonium bicarbonate buffer $(12 \mathrm{~mL}, \mathrm{pH} 8.5)$. The quenched reaction was stirred for an additional $10 \mathrm{~min}$. Lyophilization gave the crude product, which was purified using an Amersham ÄKTA FPLC system equipped with a Mono $Q^{\mathrm{TM}}$ 5/50 GL column to yield 8 (ret. time $=17 \mathrm{~min}$ ) as its triethylammonium salt (3\%). FPLC conditions: buffer A: 20 mM TEAB ( $\mathrm{pH} 7.5)$; buffer B: 1 M TEAB ( $\mathrm{pH} 7.5)$. Linear gradient of from 0 to $100 \%$ B over $30 \mathrm{~min}$ at a flow rate of $1 \mathrm{~mL} / \mathrm{min}$.

The sodium salt of $\mathbf{8}$ was prepared for extension reactions: To a solution of the triphosphate dissolved in $\mathrm{MeOH}(1.5 \mathrm{~mL})$ was added a solution of $\mathrm{NaClO}_{4}$ in acetone $(0.75 \mathrm{M})$. After standing at room temperature for $10 \mathrm{~min}$, the mixture was stored at $-80{ }^{\circ} \mathrm{C}$ for $10 \mathrm{~min}$ and spun in a table top clinical centrifuge at the highest speed for $10 \mathrm{~min}$. The solvent was decanted and the pellet was resuspended in acetone $(3 \mathrm{~mL})$, centrifuged as above, and the solvent decanted to remove excess $\mathrm{NaClO}_{4}$. This acetone-washing process was repeated 3 times. Evaporation of the remaining acetone under vacuum gave the final sodium salt, which was dissolved and stored in $20 \mathrm{mM}$ sodium phosphate buffer $\left(\mathrm{pH} \mathrm{7.2)}\right.$ at $-20{ }^{\circ} \mathrm{C}$. The concentration of the triphosphate is determined by using the extinction coefficient at $270 \mathrm{~nm}\left(10,100 \mathrm{M}^{-1} \mathrm{~cm}^{-1}\right)$ for the nucleoside. Triethylammonium salt: fluffy white solid. ${ }^{1} \mathrm{H}$ NMR $\left(\mathrm{D}_{2} \mathrm{O}\right) \delta$ 7.50-7.27 (m, 6H), $7.08(\mathrm{~s}, 1 \mathrm{H})$, $6.04(\mathrm{t}, J=6.8 \mathrm{~Hz}, 1 \mathrm{H}), 4.30-4.20(\mathrm{~m}, 1 \mathrm{H}), 4.08-3.60$ (m, 5H), 3.11 (dd, J=7.2, 7.2 Hz, 6H), 2.16$2.05(\mathrm{~m}, 1 \mathrm{H}), 1.80-1.72(\mathrm{~m}, 1 \mathrm{H}), 1.19(\mathrm{t}, J=7.2 \mathrm{~Hz}, 9 \mathrm{H}) ;{ }^{31} \mathrm{P}$ NMR $\left(\mathrm{D}_{2} \mathrm{O}\right) \delta-10.98(\mathrm{~d}, J=19.3$ 
Hz), -11.86 (d, $J=19.9 \mathrm{~Hz}),-23.39$ (t, $J=20.0 \mathrm{~Hz})$; MS (ESI) $\mathrm{m} / \mathrm{z}: 637.0([\mathrm{M}-\mathrm{H}]$, calc'd $\mathrm{m} / \mathrm{z}$ : 637.2 .

Extension Kinetics. Klenow exo- $(3.68 \mu \mathrm{M}, 0.30 \mu \mathrm{L}, 1.1 \mathrm{pmol})$ was treated with inorganic pyrophosphatase $(3.7 \mu \mathrm{L}, 40 \mathrm{U} / \mathrm{mL}, 0.148 \mathrm{U})$ in a solution of $10 \times$ BSA solution $(1 \mathrm{mg} / \mathrm{mL}$, bovine serum albumin; $2 \mathrm{mM} \mathrm{KH_{2 }} \mathrm{PO}_{4}$, $\mathrm{pH}$ 7. $0 ; 5 \mathrm{mM} \mathrm{NaCl}$; $0.01 \mathrm{mM}$ EDTA; 0.5\% glycerol; $1.2 \mu \mathrm{L}), 10 \times$ Klenow buffer (100 mM Tris-HCl, $\mathrm{pH} 7.5 ; 50 \mathrm{mM} \mathrm{MgCl} 2,75 \mathrm{mM}$ DTT; $1.2 \mu \mathrm{L}$ ) and water $(5.6 \mu \mathrm{L})$ at room temperature for $10 \mathrm{~min}$. A DNA duplex-enzyme cocktail $(2 \times)$ stock solution $(100 \mu \mathrm{L})$ was prepared by mixing the above enzyme solution $(10.8 \mu \mathrm{L})$ with the DNA solution $(30 \mu \mathrm{L}, 333 \mathrm{nM}), 10 \times$ BSA $(20 \mu \mathrm{L}), 10 \times$ Klenow buffer $(20 \mu \mathrm{L})$ and water $(19.2 \mu \mathrm{L})$. The $(2 \times)$ cocktail was incubated for $5 \mathrm{~min}$ at room temperature. The extension reactions were carried out by adding $5 \mu \mathrm{L}$ of the cocktail to the appropriate $2 \times$ dNTP solutions $(5 \mu \mathrm{L})$, which were freshly prepared from $1 \mathrm{mM}$ stock solutions of the corresponding dNTPs. After 3 min (PhSedTTP, 8) or 1 min (dTTP), the reactions were quenched with $95 \%$ formamide loading buffer $(5 \mu \mathrm{L})$ containing $10 \mathrm{mM}$ EDTA. The mixtures were heated at $90{ }^{\circ} \mathrm{C}$ for $2 \mathrm{~min}$ and cooled immediately in an ice-bath. Aliquots of the mixtures were subjected to $20 \%$ denaturing PAGE and analyzed using a Storm 840 phosphorimager. Kinetic parameters were obtained by nonlinear regression analysis of velocity versus [dNTP]. The dNTP concentrations used were as follows: 5 , $10,20,30,40,50 \mathrm{nM}$ for dTTP; $0.2,0.4,0.6,0.8,1.0 \mu \mathrm{M}$ for $\mathbf{8}$. Reaction conditions were chosen such that the maximum amount of extension was $<20 \%$.

Full length Extension Reactions. A solution $(20 \mu \mathrm{L})$ of Klenow exo- $(92 \mathrm{nM})$ was prepared and treated with inorganic pyrophosphatase as described above. A DNA duplex-enzyme solution $(40 \mu \mathrm{L})$ was prepared by mixing the above enzyme solution $(6 \mu \mathrm{L})$ with the DNA solution $(7.5$ $\mu \mathrm{L}, 333 \mathrm{nM}), 10 \times$ BSA $(5 \mu \mathrm{L}), 10 \times$ Klenow buffer $(5 \mu \mathrm{L})$ and water $(16.5 \mu \mathrm{L})$. This solution was incubated for $5 \mathrm{~min}$ at $25^{\circ} \mathrm{C}$. The extension reactions were initiated by adding $5 \mu \mathrm{L}$ of a premixed dNTP solution ( $1 \mathrm{mM} \mathrm{dATP}, 1 \mathrm{mM} \mathrm{dCTP}, 1 \mathrm{mM} \mathrm{dGTP})$, and $5 \mu \mathrm{L}$ of 8 (1 mM) or dTTP $(1 \mathrm{mM})$ solution. Aliquots $(8 \mu \mathrm{L})$ were taken and quenched with $95 \%$ formamide loading buffer $(8 \mu \mathrm{L})$ containing $10 \mathrm{mM}$ EDTA at 4, 8, 15, 30 and $60 \mathrm{~min}$. The mixtures were heated at $90{ }^{\circ} \mathrm{C}$ for 2 min and immediately cooled in an ice-bath. Aliquots $(5 \mu \mathrm{L})$ of the quenched mixtures were subjected to $20 \%$ denaturing PAGE and analyzed using a Storm 840 phosphorimager. 


\section{References:}

(1) Hong, I. S.; Greenberg, M. M. J. Am. Chem. Soc. 2005, 127, 3692-3693.

(2) Hong, I. S.; Ding, H.; Greenberg, M. M. J. Am. Chem. Soc. Accepted for publication.

(3) Maniatis, T.; Fritsch, E. F.; Sambrook, J. Molecular Cloning; Cold Spring Harbor Laboratory, Cold Spring Harbor, NY., 1982. 

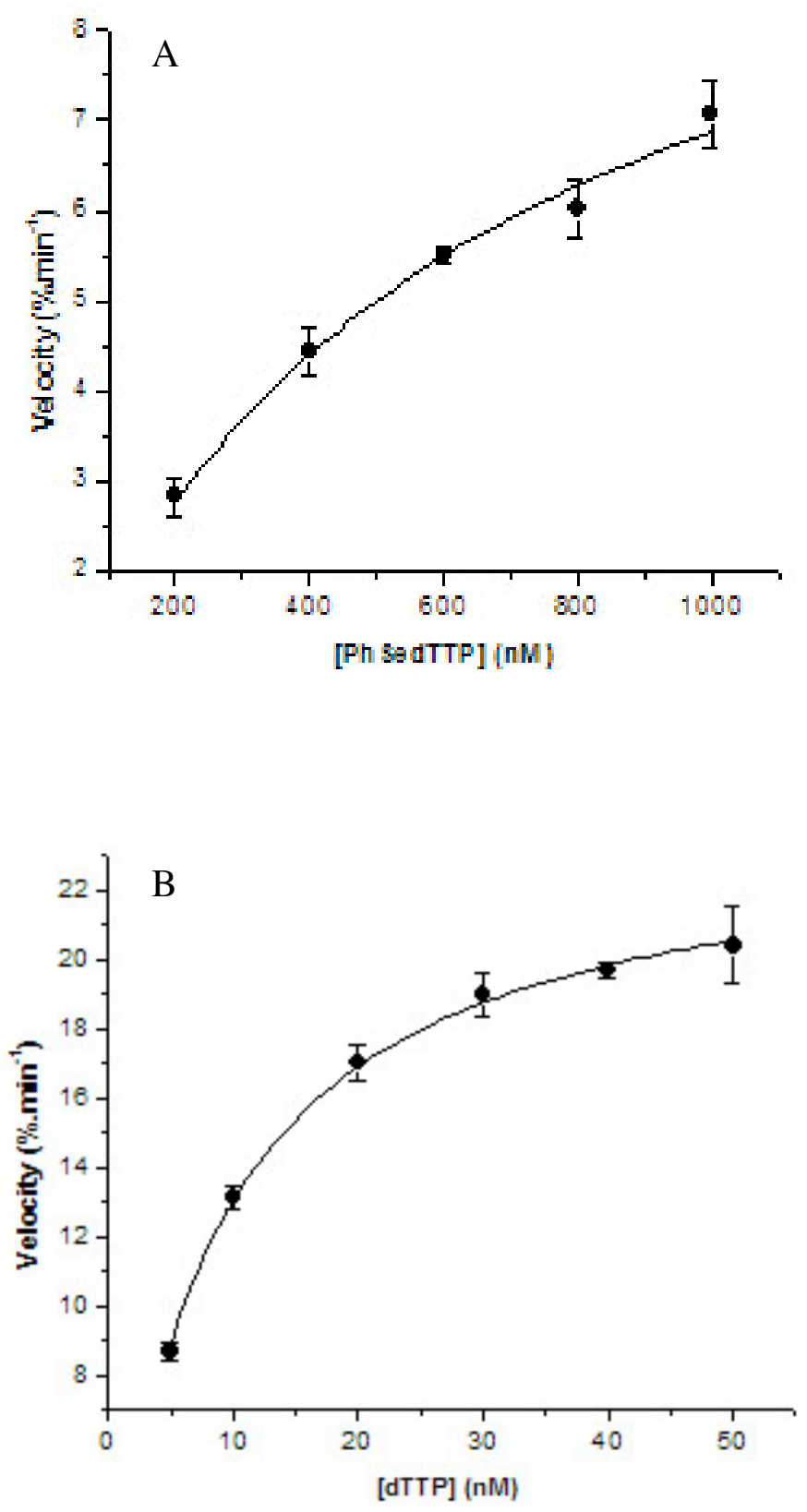

Supporting Information Figure 1. Incorporation velocity versus [dNTP] by Klenow exo-. (A) 8 (B) dTTP. 


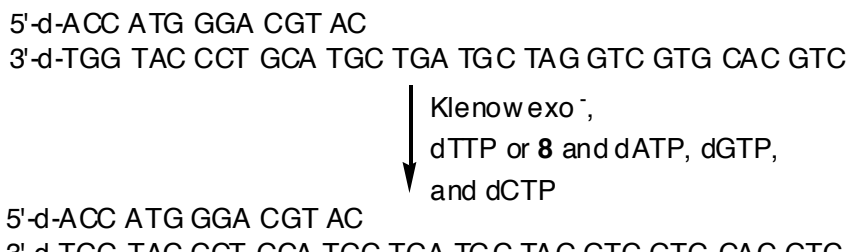
A. $\mathbf{t}=\mathbf{0}$
$60 \mathrm{~min}$
B. $\mathbf{t}=\mathbf{0}$
$60 \min$
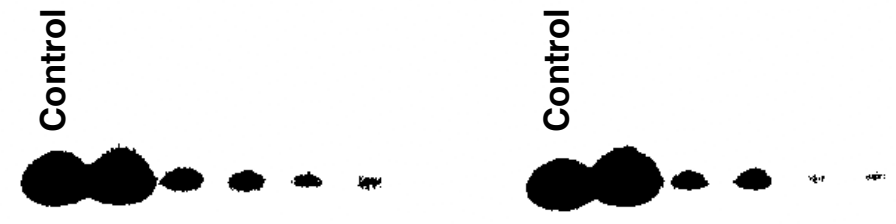

Supporting Information Figure 2. Primer extension by Klenow exo in the presence of dATP, dCTP, and dGTP (1.0 mM) and (A) dTTP or (B) 8. Control: Enzyme + DNA but no dNTP's (60 min reaction). 


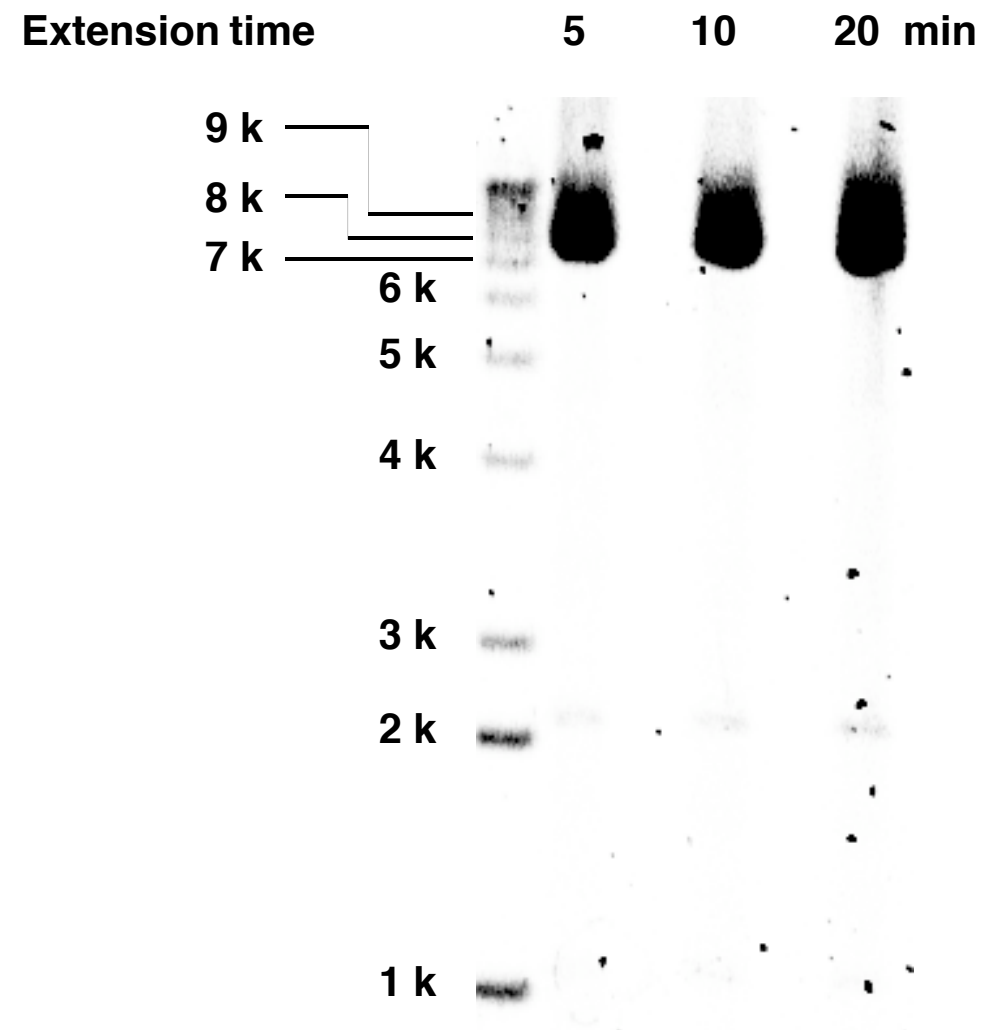

Supporting Information Figure 3. Formation of linearized duplex via Sequenase extension of primer hybridized to linearized M13mp7. Products were eluted on a $1 \%$ agarose gel. Extension was carried out using $0.2 \mathrm{U}$ Sequenase, calibrated using $1 \mathrm{~kb}$ size markers, and visualized using $\mathrm{SYBR}^{\circledR}$ Green I. 


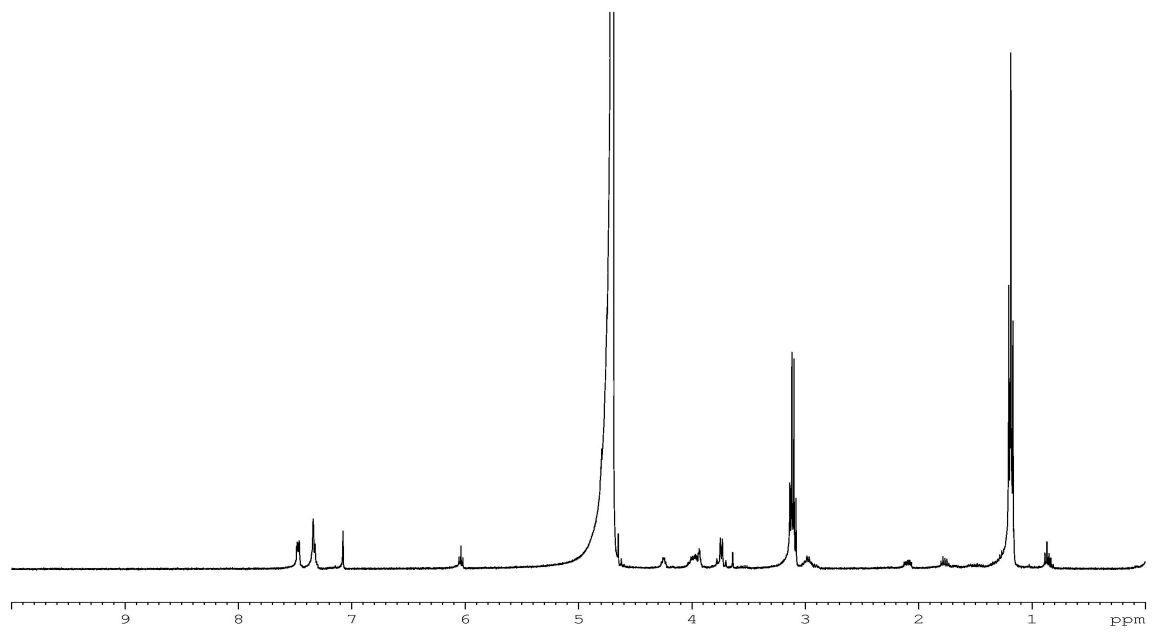

Supporting Information Figure 4. ${ }^{1} \mathrm{H}$ NMR of $\operatorname{PhSedTTP~(8).~}$

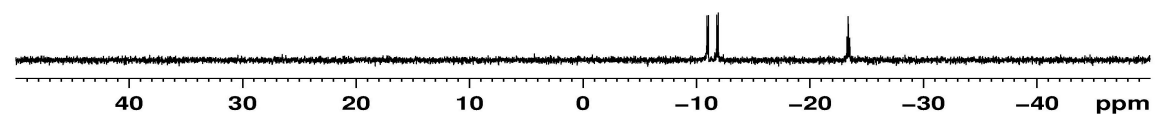

Supporting Information Figure 5. ${ }^{31} \mathrm{P}$ NMR of $\operatorname{PhSedTTP~(8).~}$ 